\title{
A béltartalom és a vizelet mikrobiom-összetételének onkológiai vonatkozásai
}

\author{
Oláh Csilla $^{1 *}$ - Váradi Melinda ${ }^{1 *}$ - Horváth Orsolya dr. ${ }^{2}$ \\ Nyirády Péter dr. ${ }^{1}$. Szarvas Tibor dr. ${ }^{1,3}$ \\ ${ }^{1}$ Semmelweis Egyetem, Általános Orvostudományi Kar, Urológiai Klinika, Budapest \\ ${ }^{2}$ Országos Onkológiai Intézet, Urogenitális Tumorok és Klinikai Farmakológiai Osztály, Budapest \\ ${ }^{3}$ Duisburg-Essen Egyetem, Urológiai Klinika, Essen
}

\begin{abstract}
Az immunrendszer nem megfelelő múködése meghatározó szerepet játszik a daganatok kialakulásában, progressziójában és az egyes terápiák hatékonyságában is. A bélrendszer baktériumai a szervezet immunitásán keresztül képesek befolyásolni a szervezet gyógyszeres terápiákra adott válaszreakcióját, kiváltképpen az immunellenőrzőpont-gátló kezelések hatását. Az újgenerációs nukleinsav-szekvenálási technológiák felhasználásával részletes képet kaphatunk a szervezetben jelen lévő baktériumok minőségi és mennyiségi viszonyairól. A közelmúltban összefüggést igazoltak a vastagbéldaganat, a melanoma, a vesesejtes carcinoma és a nem kissejtes tüdőrák esetén alkalmazott immunellenőrzőpont-gátló terápiák hatékonysága és a bél mikrobiom-összetétele között. Számos olyan baktériumot azonosítottak, melynek jelenlétéből, illetve mennyiségéből következtethetünk az egyes kezelésekkel szembeni egyéni érzékenységre. Ezzel összhangban, az antibiotikumkezelés által okozott dysbiosis növelte az immunellenőrzőpont-gátló terápia sikertelenségének kockázatát. Ezen eredmények tükrében a jövőben a mikrobiom-összetétel meghatározása is fontos tényező lehet az immunterápiák hatékonyságának elörejelzésében, illetve egyre inkább bizonyított, hogy a széles spektrumú antibiotikumkezelés a legtöbbször csökkenti a daganatellenes immunterápiák hatékonyságát. Jelenleg folyó klinikai vizsgálatok pedig a mikrobiom-összetétel mesterséges úton történő megváltoztatásának terápiás lehetőségeit tanulmányozzák. Bebizonyosodott, hogy a korábbi állásponttal szemben a vizelet nem steril. DNS-szekvenálás alkalmazásával számos olyan, a vizeletben előforduló baktériumot sikerült azonosítani, melynek jelenléte hozzájárulhat a húgyhólyagrák kialakulásához és progressziójához, illetve a húgyhólyagban lokálisan alkalmazott BCG-terápia hatékonyságához. Jelen munkában a közelmúlt publikációit feldolgozva összefoglaljuk, mely baktériumok jelenléte hozható összefüggésbe a különböző daganatok kialakulásával, progressziójával és terápiarezisztenciájával.

Orv Hetil. 2020; 162(15): 579-586.
\end{abstract}

Kulcsszavak: immunellenőrzőpont-gátló kezelés, terápiarezisztencia, mikrobiom-összetétel, antibiotikumkezelés, újgenerációs szekvenálás (NGS)

\section{Oncological relevance of gut and urine microbiomes}

Dysfunction of the immune system plays a crucial role in the development and progression of cancer as well as the effectiveness of antitumor therapies. Gut microbiota, due to their impact on the immune system, are able to influence response to anticancer drug therapies. Next-generation DNA-sequencing technologies enabled a comprehensive quantitative and qualitative exploration of the gut microbiome. An increasing body of evidence indicates the association between the efficacy of immune checkpoint inhibitor therapies and gut microbiome composition in colorectal cancer, malignant melanoma, renal cell carcinoma, and non-small cell lung cancer. Recently, several bacterial strains and species were shown to be associated with treatment efficacies. In accordance, dysbiosis caused by antibiotic treatment was found to increase the risk of failure to immune checkpoint inhibitor therapies. In the light of these results, examination of microbiome composition may become an important factor for the prediction of immunotherapies. Currently ongoing clinical trials are investigating the potential of therapeutic alteration of microbiome composition. Contrary to the previous view, urine has been shown not to be sterile. By using sensitive DNA-sequencing technologies, several urinary bacteria could be identified which may contribute to the development and progression of bladder cancer and may influence the efficacy of intravesical BCG therapy. In the present work, we summarize recent studies that identified the presence of certain bacteria associated with the development, progression, and therapy resistance of various cancers.

*A két szerző egyenlő mértékben járult hozzá a cikk megszületéséhez. 
Keywords: immune checkpoint inhibitor therapy, therapy resistance, microbiome composition, antibiotic therapy, next-generation sequencing technologies (NGST)

Oláh Cs, Váradi M, Horváth O, Nyirády P, Szarvas T. [Oncological relevance of gut and urine microbiomes]. Orv Hetil. 2020; 162(15): 579-586.

(Beérkezett: 2020. szeptember 10.; elfogadva: 2020. október 8.)

\begin{abstract}
Rövidítések
$16 \mathrm{~S}$ rRNS = $16 \mathrm{~S}$ riboszomális ribonukleinsav; $\mathrm{BCG}=$ Bacillus Calmette-Guérin; $\mathrm{CD}=$ (cluster of differentiation) differenciálódási klaszter; $\mathrm{CI}=$ (confidence interval) konfidenciaintervallum; CTLA = citotoxikus T-lymphocyta-antigén; DNS = dezoxiribonukleinsav; ERK = extracelluláris szignál regulálta kináz; $\mathrm{HR}=($ hazard ratio) relatív kockázat; IEG = immunellenőrzőpont-gátló; $\mathrm{MEK}=$ mitogénaktivált proteinkináz; $\mathrm{MM}=\mathrm{me}$ tastaticus melanoma; NGST $=$ (next-generation sequencing technologies) újgenerációs szekvenálási technológiák; NKFIH = Nemzeti Kutatási, Fejlesztési és Innovációs Hivatal; NSCLC $=($ non-small-cell lung cancer $)$ nem kissejtes tüdőrák; NVKP = Nemzeti Versenyképességi és Kiválósági Program; PDI = (programmed cell death protein 1) programozott sejthalál fehérje-1; PDLl = PDl-ligand; RNS = ribonukleinsav; $\mathrm{T}_{\mathrm{H}} \mathrm{l}=$ ( T helper cell 1 ) 1 -es típusú segítő T-sejt; WNT = (winglessrelated integration site) szárny nélküli integrációs hely
\end{abstract}

Az emberi szervezettel számos mikroorganizmus, köztük baktériumok, vírusok és gombák élnek kölcsönhatásban, melyek bőrünkön és minden hámeredetü szövetünk felszínén megtalálhatók [1]. Napjainkban jelentősen növekszik azon kutatások száma, melyek célja a mikrobiom összetételének és funkciójának megismerése. A mikrobiom egyénre jellemző összetételét számos tényező befolyásolhatja, úgymint a környezet, a táplálkozás és a genetikai tényezők. Ennek következtében egészséges emberek mikrobiom-összetétele között is jelentős különbségek adódhatnak [2]. A megfelelő baktériumflóra meghatározó, hiszen megakadályozhatja a patogén baktériumok elterjedését és ezzel különböző fertőzések, gyulladások kialakulását [3]. A bélrendszerben élő mikrobaközösség összetételének szintén komoly jelentőséget tulajdonítanak. A bél mikrobiom-összetétele jelentős mértékben befolyásolja a vastagbélrák kialakulását, valamint a kezeléshez használt kemo- vagy immunterápiás szerek hatékonyságát, mivel az egyénre jellemző baktériumok az anyagcseretermékeiken keresztül aktiválhatják, illetve elnyomhatják a szervezet immunrendszerét. Mindemellett a sejtek anyagcseréjét befolyásolva az egyes gyógyszerek hatását is megváltoztathatják [4]. Ezzel szemben más baktériumok képesek bizonyos toxinok és rákkeltő anyagok hatástalanítására is [5], akadályozva ezzel a daganatok kialakulását. Az újgenerációs nukleinsav-szekvenálási technológiák és a bioinformatika térhódítása által átfogó képet kaphatunk a szervezetünkben jelen lévő baktérium-összetételről. A mikrobiom-összetétel meghatározására elterjedt módszer a $16 \mathrm{~S}$ riboszomális RNS (rRNS) szekvenálása, mely a $16 \mathrm{~S}$ rRNS génjének hipervariábilis régióit (VI-V9) használja fel a baktériumtaxonok azonosítására [6]. Szintén elterjedt, bár jóval költségesebb módszer az ún. shotgun metagenom szekvenálás, amelylyel a mintánkban található mikroorganizmusok teljes genomösszetétele határozható meg, így a baktériumok mellett a gombák és a vírusok jelenlétéről, továbbá azok mennyiségi összetételéről is információt gyüjthetünk. Ez a módszer a mikroorganizmusok génkészletéról is teljes képet ad, ezért nem csupán azok jelenlétérôl és összetételérôl, hanem biológiai funkcióikról is részletes információt szolgáltat $[7,8]$.

Bebizonyosodott, hogy a korábban általánosan elfogadott állásponttal szemben a vizelet nem steril. Erre utal, hogy nemcsak valamely gyulladásos folyamattal kapcsolatban, hanem egészséges emberek vizeletéból is sikerült baktériumokat meghatározni. Korábban tenyésztéssel ezen baktériumokat nem sikerült kimutatni, manapság azonban a nukleinsav-szekvenálás módszerével számos taxon jelenlétét sikerül igazolni, ami részben abból is adódhat, hogy ez utóbbi módszer nemcsak az élő, hanem az elhalt baktériumokat is képes azonosítani [9]. A vizelet-mikrobiom vizsgálatakor azonban számításba kell vennünk, hogy a mintavételezés során esetlegesen fellépő genitalis kontamináció torzíthatja a baktériumközösség összetételét [10]. A vizeletben leginkább előforduló baktériumfajok: Lactobacillus, Corynebacterium, Streptococcus, Actinomyces és Staphylococcus. Feltételezhetően - a bélrendszer mikrobiom-összetétele és a vastagbélrák kialakulása közötti kapcsolathoz hasonlóan - a vizeletben lévő baktériumoknak szerepük lehet a prosztatarák kialakulásában. A prosztatagyulladás hátterében gyakran valamely baktérium jelenléte áll, mint például az Escherichia coli vagy Enterococcus-fajok. A gyulladás pedig morfológiai változásokat (dysplasia, hyperplasia) idézhet elö, növelve a prosztatarák kialakulásának valószínúségét. A patogén baktériumok elszaporodása és a prosztatarák kialakulása közötti kapcsolat megerősítésére azonban még számos további kutatás szükséges [11]. Egyre több eredmény lát napvilágot a vizelet mikrobiom-összetétele és a húgyhólyagrák kialakulásának kapcsolatáról is.

A jelen dolgozattal az elmúlt 5 év publikációit feldolgozva arról szeretnénk átfogó képet nyújtani, hogy mely baktériumok jelenléte hozható összefüggésbe a különböző daganatok kialakulásával, progressziójával és terápiarezisztenciájával. Emellett kitérünk a vizelet mikrobiom-közösségének a húgyhólyagdaganatban betöltött esetleges szerepére. 


\section{Bélbaktériumok mint prognosztikai és prediktív faktorok}

A bélben élő mikrobiom-közösség hatással van a szervezet immunitására, melyen keresztül befolyásolja a szervezet gyógyszeres terápiákra adott válaszreakcióját is, kiváltképpen az immunellenőrzőpont-gátló (IEG-) kezelések hatását. Az immunrendszer nem megfelelő múködése komoly szerepet játszik a rákos megbetegedések kialakulásában, a betegség progressziójában és egyes terápiák hatékonyságában. A terápiák hatékonyságát számtalan tényező modulálhatja, mint például a daganatsejtek anyagcseréje, illetve a szervezet immunitását elkerülő mechanizmusok megléte. Mindezek mellett a daganatsejt mikrokörnyezete is döntő szerepet játszik a betegség lefolyásában, ilyen tényező az immunsejtek jelenléte vagy hiánya, melyet befolyásol a bél mikrobiom-közössége is. A baktériumok az anyagcseretermékeiken, úgynevezett patogénasszociált molekuláris mintázaton keresztül immunválaszt váltanak ki, melynek során serkentik az antigénprezentáló sejtek érését, úgymint a dendritikus sejtekét. Ezen sejtek képesek aktiválni naiv T-sejteket CD4 ${ }^{+}$T-sejtekké és 'helper' (segítő) T-sejtekké, valamint serkentik a $\mathrm{CD}^{+}$T-sejtek múködését [12]. Egyes mikrobák azonban el is nyomhatják a szervezet immunitását, közvetve hozzájárulva ezzel a daganat kialakulásához, továbbá anyagcseretermékeiken keresztül közvetlenül onkogén hatásúak is lehetnek [13]. Erre példa a Helicobacter pylori, amely a gyomorrák kialakulásában játszik szerepet úgy, hogy citotoxinjai révén a sejt autofágiájában és apoptózisában zavart okoz, továbbá aktiválja az onkogén Ras/MEK/ERK és $\beta$-katenin-jelátviteli útvonalakat. Összefüggést találtak a gyomorrák kialakulása és a Fusobacterium nucleatum baktérium előfordulása között is. Ez a baktérium közvetlen kapcsolatba kerül a bél epithelsejtjeivel, aminek következtében a $\beta$-katenin- és WNT-jelátviteli útvonalakat aktiválva gyulladást és carcinogenesist idéz elő. Ezzel összhangban a tumorban a $F$. nucleatum jelenléte a szervezet csökkent immunválaszával és a betegek rövidebb túlélésével mutatott összefüggést [14]. Hasonlóképpen, a F. nucleatum jelenléte a vastagbéldaganat esetében is összefüggést mutatott a kemoterápia-rezisztenciával és a betegek csökkent túlélésével [13].

A bélbaktériumok képesek befolyásolni számos gyógyszeres terápia hatékonyságát, beleértve a kemo- és immunterápiát is (1. táblázat). Kemoterápia-rezisztenciát többek között Proteobacteria-fajok jelenlétekor bizonyítottak urogenitalis daganatok esetében, melyek anyagcseréjük révén akadályozták a gemcitabin hatását [15]. A ciklofoszfamid hatását szintén képesek megváltoztatni a bélben jelen lévő baktériumok [16]. A szert széles körben alkalmazzák autoimmun betegségeknél, vér- és csontvelő-transzplantációnál és daganatos betegségeknél is, amelyeknél a szer immunrendszert stimuláló hatását használják ki [17]. Egerekben egyes Gram-pozitív baktériumok (Lactobacillus johnsonii, Lactobacillus murinus,
1. táblázat $\mid$ A daganatos betegek székletében prognosztikus vagy prediktív faktorként azonosított baktériumok

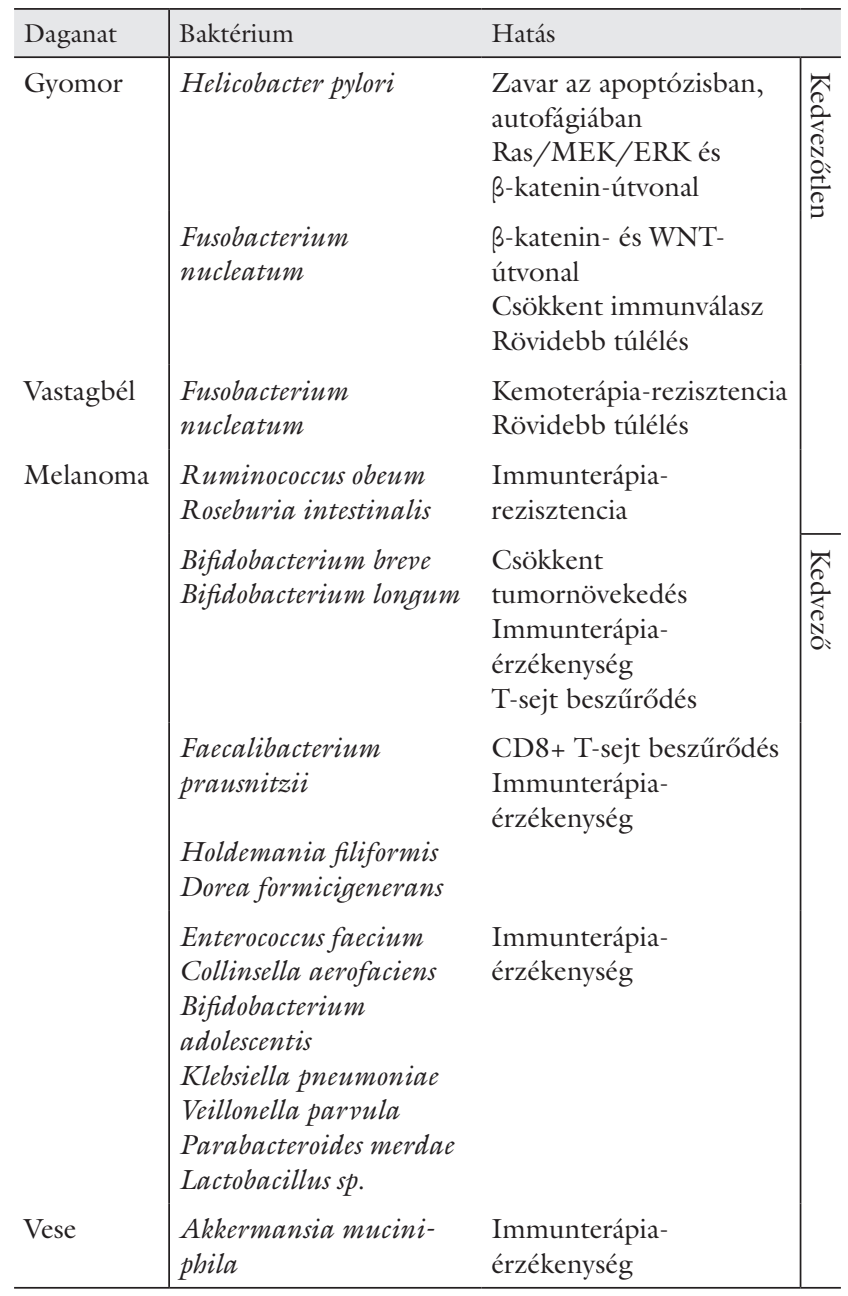

ERK $=$ extracelluláris szignál regulálta kináz; $\mathrm{MEK}=$ mitogénaktivált proteinkináz; WNT = szárny nélküli integrációs hely

Enterococcus hirae) esetén igazolták, hogy jelenlétükkel növelték a ciklofoszfamid révén kiváltott segítő T-sejtek által közvetített immunválaszt. Mindazonáltal a ciklofoszfamid is hatással van a gastrointestinalis baktériumközösség összetételére [16]. A ciklofoszfamidkezelés következtében egerekben megnőtt a Firmicutes törzs jelenléte, míg a Bacteroidetes törzsé csökkent [17]. Ezzel összhangban, anti-CTLA4-immunterápiával történő kezelés során daganatos egerek (MCA205-sarcoma) székletében szintén a Clostridiales rend elszaporodását észlelték, amivel párhuzamosan a Bacteroidales rend jelenléte csökkent [18].

Az IEG-terápia alkalmazása tartós javulást eredményezett számos daganatféleségben, olyan késői stádiumban is, amikor az addigi standard kezelések már kudarcot vallottak $[19,20]$. Ismert, hogy a tumorsejtek ligandokat képesek termelni, melyek gátló hatást fejtenek ki az elpusztításukra hivatott T-sejtekre, ezzel blokkolva a tumorellenes immunválasz hatékony kifejlődését. Az IEG-k olyan monoklonális antitestek, melyek megakadályozzák 
ezt a gátlást, így a T-sejtek továbbra is múködőképesek maradnak. A daganatos betegek többsége azonban rezisztenciát mutat az IEG-szerekkel szemben (PDI/ PDL1; CTLA4), ezért is lenne fontos ismerni azon tényezőket, amelyek befolyásolják e szerek hatékonyságát. Európában jelenleg malignus melanoma, fej-nyaki daganatok, vesedaganat, húgyhólyagdaganat és nem kissejtes tüdőrák előrehaladott eseteiben alkalmaznak IEG-terápiákat [20].

Sivan és kollégái (2015) melanomasejtekkel subcutan oltott egereken végzett kísérletekben igazolták, hogy egyes baktériumok jelenléte jótékonyan befolyásolja az immunterápia hatékonyságát. A T-sejtek beszűrődése a tumorsejtek mikrokörnyezetébe alapvetően javítja az immunterápiára adott válaszreakciót és ezzel a betegségfüggő túlélést. Eredményeik alapján a mikrobiom-összetétel nemcsak az anti-PDLl-terápia hatékonyságára ('InVivoMAb anti-mouse PD-Ll [B7-Hl]'; Bio X Cell, Lebanon, NH, Amerikai Egyesült Államok), de a tumor progressziójára is hatással volt. Kutatásuk során a $16 \mathrm{~S}$ rRNS szekvenálásának módszerével bifidobaktériumfajokat (Bifidobacterium breve, Bifidobacterium longum) azonosítottak, melyek azon egerek bélrendszerében voltak jelen nagy mennyiségben, amelyeknél csökkent tumornövekedést és hatékonyabb terápiás választ igazoltak. Amennyiben a terápiára rezisztens egerekbe oralis adagolás útján vagy széklettranszplantációval bejuttatták a fent említett bifidobaktériumfajokat, azok érzékennyé váltak az anti-PDLl-kezelésre. Ebben az esetben a tumornövekedés mérséklődése mellett a tumorsejtek mikrokörnyezetében a $\mathrm{CD} 8^{+} \mathrm{T}$-sejt nagyobb arányú beszürődését is megfigyelték [21]. Klinikai vizsgálat során 42, áttétes melanomában szenvedő beteg székletében előforduló baktériumokat elemeztek $16 \mathrm{~S}$ rRNS, valamint a teljes metagenom szekvenálásának módszerével, mellyel megerősítették, hogy a kezelés előtti mikrobiom-összetétel meghatározó az anti-PDl-terápia hatékonyságának szempontjából. A bifidobaktériumtörzsek ebben az esetben is nagyobb mennyiségben voltak jelen az anti-PDIterápiára érzékeny betegek szervezetében. Szekvenálás és PCR-módszer alkalmazásával a következő baktériumokat azonosították az immunterápiára érzékeny betegek esetében: Enterococcus faecium, Collinsella aerofaciens, Bifidobacterium adolescentis, Klebsiella pneumoniae, Veillonella parvula, Parabacteroides merdae, Lactobacillus sp. és a már egereknél is azonosított Bifidobacterium longum. Továbbá a terápiára rezisztens betegek esetében a Ruminococcus obeum és a Roseburia intestinalis jelenlétét igazolták. Eredményeiket állatkísérletekkel is alátámasztották, melyek során melanomasejtekkel subcutan oltott, baktériummentes környezetben tenyésztett egerekbe a terápiára jól reagáló betegek székletét juttatva azt tapasztalták, hogy az anti-PDl-kezelés hatékonyan csökkentette a tumornövekedést. Ezzel szemben a terápiarezisztens betegek székletével oralisan kezelt egerek kevésbé reagáltak az immunkezelésre [22].
Az egérkísérletek során elért, látványosan pozitív eredmények más kutatócsoport figyelmét is felkeltették. Gopalakrishnan és mtsai 112, melanomával diagnosztizált beteg mikrobiom-összetételét vizsgálva azt találta, hogy a székletben jelen lévő magasabb fajszám kedvezően befolyásolja az immunterápiára adott választ, amit radiológiai módszerrel igazoltak. Az immunterápiára érzékeny betegeknél Clostridialest, a rezisztensekben Bacteroidalest azonosítottak nagyobb mennyiségben. A Clostridiales renden belül a teljesgenom-szekvenálás módszerével azonosították a Faecalibacterium nemzetséget, amely a jobb progressziómentes túléléssel mutatott szignifikáns összefüggést. Továbbá a Faecalibacterium nemzetség tagjainak jelenléte a tumorszövet eröteljesebb $\mathrm{CD}^{+}$T-sejt infiltrációjával is együtt járt [23]. Mindkét fenti kutatás esetében fontos megjegyezni, hogy az anti-PDl-terápiára érzékeny és rezisztens betegcsoportok klinikai és patológiai paraméterei hasonlóak voltak, tehát azok alapján nem lehetett volna elkülöníteni a kezelésre jól reagáló és az arra rezisztens betegeket.

Egy átfogó kísérlet során, melyben több IEG-kezelés hatását is vizsgáltak metastaticus melanoma (MM) esetén, szintén kimutatták, hogy a bél mikrobiom-közössége meghatározó a gyógyszeres terápia szempontjából. A Firmicutes törzsbe (a Clostridiales renden belül) sorolt fajok (Faecalibacterium prausnitzii, Holdemania filiformis, Dorea formicigenerans) jelenlétét igazolták az antiCTLA4-re és anti-PDl-re érzékeny betegek székletében. Ezenfelül szintén alátámasztották, hogy a $F$. prausnitzii a tumorsejtek $\mathrm{CD}^{+}{ }^{+} \mathrm{T}$-sejtek általi erőteljesebb infiltrációjával is összefüggést mutatott [24]. Az anti-CTLA4terápiára rezisztens betegek esetén is igazolták a Bacteroides nemzetség jelenlétét, amely a rosszabb prognózissal mutatott összefüggést [25]. Ezzel szemben Vétizou és mtsai (2015) kutatásuk során 25 MM-beteget vizsgálva azt tapasztalták, hogy a Bacteriodes fajok fokozott jelenléte a székletben éppen a jobb terápiás hatékonysággal mutat összefüggést. Eredményeiket állatkísérletekkel is igazolták; az anti-CTLA4-terápiára reagáló melanomás, illetve nem kissejtes tüdőrákos betegek székletét egerekbe transzplantálták, aminek hatására azokban csökkent a tumornövekedés. Az egerek székletéből kimutatták, hogy a Bacteriodales törzs egyedei sikerrel kolonizálták a korábban baktériummentes egerek bélrendszerét [18]. Vesesejtes carcinomában szenvedő betegeknél kimutatták, hogy a magasabb fajszám az anti-PDl-terápiára való érzékenységgel mutat összefüggést, ezenfelül azonosították az Akkermansia muciniphila baktériumot, melynek jelenléte a jobb teljes és progressziómentes túléléssel korrelált. Továbbá a kutatás során igazolták az antibiotikumkezelés és az immunterápia-rezisztencia közötti öszszefüggést [26]. A későbbiekben megerősítették az antibiotikumkezelésre vonatkozó eredményeiket, miszerint a terápia előtti 30 napon belül alkalmazott antibiotikumkezelés jelentősen, több mint háromszorosára növeli mind a daganatprogresszió (progressziómentes túlélés: 
2. táblázat |Az IEG-terápia megkezdése előtt/alatt alkalmazott antibiotikumkezelés hatása a terápia hatékonyságára [26-39]

\begin{tabular}{|c|c|c|c|c|c|c|c|c|c|c|c|}
\hline \multirow{2}{*}{$\begin{array}{l}\text { A daganat } \\
\text { típusa }\end{array}$} & \multirow[t]{2}{*}{$\mathrm{n}$} & \multirow{2}{*}{$\begin{array}{l}\text { Terápia } \\
\text { (IEG) }\end{array}$} & \multicolumn{3}{|c|}{ Antibiotikumkezelés } & \multicolumn{3}{|l|}{ Univariancia } & \multicolumn{2}{|c|}{ Multivariancia } & \multirow{2}{*}{$\begin{array}{l}\text { Hivat- } \\
\text { kozás }\end{array}$} \\
\hline & & & $\mathrm{n}$ & Típus & $\begin{array}{l}\text { Idózítés az IEG } \\
\text { kezdetéhez képest }\end{array}$ & OS/PFS változás & HR & $\mathrm{p}$ & HR & $\mathrm{p}$ & \\
\hline NSCLC & 74 & a-PDl & 15 & na & $\begin{array}{l}3 \text { hó PRE / } \\
\text { immunterápia } \\
\text { alatt }\end{array}$ & $\begin{array}{l}\text { PFS: nincs } \\
\text { változás }\end{array}$ & na & 0,72 & na & na & {$[28]$} \\
\hline \multirow[t]{2}{*}{ NSCLC } & \multirow[t]{2}{*}{140} & \multirow[t]{6}{*}{ a-PDl } & \multirow[t]{2}{*}{37} & \multirow{6}{*}{$\begin{array}{l}\beta \text {-Laktám } \pm \text { inhibitor } \\
\text { Fluorokinolon } \\
\text { Makrolid }\end{array}$} & \multirow{6}{*}{$\begin{array}{l}2 \text { hó PRE / } 1 \text { hó } \\
\text { POST }\end{array}$} & $\downarrow$ PFS (0,7 hó) & na & 0,571 & na & na & {$[26]$} \\
\hline & & & & & & $\downarrow$ OS (7 hó) & 2,28 & 0,002 & 2,21 & 0,004 & \\
\hline \multirow[t]{2}{*}{ RCC } & \multirow[t]{2}{*}{67} & & \multirow[t]{2}{*}{20} & & & $\downarrow \operatorname{PFS}(3,1$ hó $)$ & 2,15 & 0,015 & 2,12 & 0,026 & \\
\hline & & & & & & $\downarrow$ OS $(4,5$ hó $)$ & na & 0,154 & na & na & \\
\hline \multirow[t]{2}{*}{$\mathrm{UC}$} & \multirow[t]{2}{*}{42} & & \multirow[t]{2}{*}{12} & & & $\downarrow$ PFS $(2,5$ hó $)$ & 2,15 & 0,056 & 1,96 & 0,094 & \\
\hline & & & & & & $\begin{array}{l}\downarrow \text { OS } \\
(11,5 \text { hó vs. NR })\end{array}$ & na & 0,098 & na & na & \\
\hline \multirow[t]{2}{*}{ NSCLC } & \multirow[t]{2}{*}{239} & \multirow{2}{*}{$\begin{array}{l}\text { a-PDLl/ } \\
\text { a-PDl }\end{array}$} & \multirow[t]{2}{*}{68} & \multirow[t]{2}{*}{ na } & 2 hó PRE & $\downarrow$ PFS (1 hó) & na & 0,236 & na & na & \\
\hline & & & & & & $\downarrow$ OS (12,1 hó) & na & 0,002 & na & na & \\
\hline NSCLC & 30 & a-PDl & 11 & Penicillin & 1 hó PRE / I hó & $\downarrow \operatorname{PFS}(0,2$ hó $)$ & 2,5 & 0,032 & 5,34 & 0,028 & [29] \\
\hline & & & & $\begin{array}{l}\text { Fluorokinolon } \\
\text { Karbapenem }\end{array}$ & POST & $\downarrow$ OS $(7,6$ hó $)$ & 4,29 & 0,038 & 14,81 & 0,026 & \\
\hline NSCLC & 239 & a-PDl/ & 48 & $\beta$-Laktám \pm inhibitor & 1 hó PRE & $\downarrow$ PFS (1,9 hó) & 1,4 & 0,04 & 1,3 & 0,17 & {$[27]$} \\
\hline & & $\begin{array}{l}\mathrm{a}-\mathrm{PDI}+ \\
\mathrm{CTLA} 4\end{array}$ & & $\begin{array}{l}\text { Kinolon } \\
\text { Szulfonamid }\end{array}$ & & $\downarrow$ OS (16,7 hó) & 2,9 & $<0,01$ & 2,5 & $<0,01$ & \\
\hline RCC & 121 & & 16 & & & $\downarrow$ PFS $(5,5$ hó $)$ & 2,3 & $<0,01$ & 2,2 & $<0,01$ & \\
\hline & & & & & & $\downarrow$ OS (13,3 hó) & 2,4 & 0,04 & 2,1 & 0,11 & \\
\hline Különböző & 60 & $\mathrm{a}-\mathrm{PD} 1 /$ & 17 & Cefalosporinok & 14 nap PRE / 14 & $\downarrow$ PFS & 1,6 & 0,048 & na & 0,01 & {$[30]$} \\
\hline típusok & & a-PDLl & & $\begin{array}{l}\text { Vankomicin } \\
\text { Ciprofloxacin }\end{array}$ & nap POST & $\downarrow$ OS (15 hó) & 2,9 & 0,003 & na & 0,038 & \\
\hline NSCLC & 168 & a-PDl & 80 & na & 2 hó PRE / 1 hó & $\downarrow$ PFS (2,3 hó) & na & 0,028 & na & na & {$[31]$} \\
\hline & & & & & POST & $\downarrow$ OS $(3,8$ hó $)$ & na & 0,026 & na & na & \\
\hline NSCLC & 109 & a-PDl & 87 & $\begin{array}{l}\text { Penicillin } \\
\text { Kinolon }\end{array}$ & $\begin{array}{l}1 \text { hó PRE / } 1 \text { hó } \\
\text { POST }\end{array}$ & $\downarrow$ OS (11,8 hó) & 0,29 & 0,0004 & na & na & {$[32]$} \\
\hline RCC & 146 & a-PDl/ & 31 & $\beta$-Laktám \pm inhibitor & 2 hó PRE / 1 hó & $\downarrow$ PFS (5,5 hó) & 2,03 & 0,005 & na & na & {$[33]$} \\
\hline & & a-PDLl & & Fluorokinolon & POST & $\downarrow$ OS & 1,47 & 0,257 & na & na & \\
\hline NSCLC & 157 & $\mathrm{a}-\mathrm{PDl} /$ & 27 & Levofloxacin & 1 hó PRE / 3 hó & $\downarrow \operatorname{PFS}(1,1$ hó $)$ & na & 0,177 & na & na & {$[34]$} \\
\hline & & $\begin{array}{l}\text { a-PDLl, } \\
\text { a-PD1 + } \\
\text { CTLA4 }\end{array}$ & & Amoxicillin & POST & $\downarrow$ OS (6 hó) & na & 0,249 & na & na & \\
\hline MM & 74 & a-CTLA4/ & 10 & $\beta$-Laktám \pm inhibitor & 1 hó PRE & $\downarrow$ PFS (4,9 hó) & 0,28 & 0,01 & 0,32 & 0,02 & {$[35]$} \\
\hline & & a-PDl & & & & $\downarrow$ OS $(7,6$ hó $)$ & 0,52 & 0,17 & 0,5 & 0,13 & \\
\hline NSCLC & 72 & a-PDl & 30 & $\beta$-Laktám \pm inhibitor & 2 hó PRE / 1 hó & $\downarrow$ PFS (0,5 hó) & na & 0,249 & 1,6 & 0,645 & {$[36]$} \\
\hline & & & & Vankomicin & POST & $\downarrow$ OS $(8,3$ hó $)$ & na & 0,0027 & 2,2 & 0,038 & \\
\hline MM & 179 & a-PDl & 54 & na & 14 nap PRE / 42 & $\downarrow$ PFS (3 hó) & 1,564 & 0,003 & 1,401 & 0,033 & {$[37]$} \\
\hline NSCLC & 64 & & 25 & & nap POST & $\downarrow$ OS (11,3 hó) & 1,699 & 0,002 & 1,473 & 0,033 & \\
\hline RCC & 48 & & 13 & & & & & & & & \\
\hline NSCLC & 119 & a-PDl/ & 29 & Penicillin & 1 hó PRE & $\downarrow$ OS (24 hó) & 7,4 & $<0,001$ & 3,4 & $<0,001$ & {$[38]$} \\
\hline MM & 38 & a-PDLl & & & & & & & & & \\
\hline egyéb & 39 & & & & & & & & & & \\
\hline NSCLC & 90 & a-PDl & 13 & Trimetoprim & 1 hó PRE & $\downarrow$ PFS (3,2 hó) & na & 0,04 & na & na & [39] \\
\hline & & & & & & $\begin{array}{l}\downarrow \text { OS } \\
(8,8 \text { hó vs. NR })\end{array}$ & na & 0,037 & 2,02 & 0,19 & \\
\hline
\end{tabular}

CTLA = citotoxikus T-lymphocyta-antigén; HR = relatív kockázat; IEG = immunellenőrzőpont-gátló; MM = metastaticus melanoma; na = nem elérhető; OS = teljes túlélés; NSCLS = nem kissejtes tüdőrák; PDI = programozott sejthalál fehérje-1; PDL1 = PDl-ligand; PFS = progressziómentes túlélés; $\mathrm{RCC}=$ vesesejtes carcinoma; UC = urothelialis carcinoma 
1,9 vs. 7,4 hónap, HR: 3,1; 95\% CI: 1,4-6,9; p<0,01), mind pedig a halálozás (teljes túlélés: 17,3 vs. 30,6 hónap, HR: 3,5; 95\% CI: 1,1-10,8; p = 0,03) kockázatát. $\mathrm{Az}$ antibiotikumkezelés immunterápiára gyakorolt hatását nem kissejtes tüdőrákban is vizsgálták; a vesedaganathoz hasonlóan azt tapasztalták, hogy az antibiotikumok használata jelentősen rontotta a betegek túlélési esélyeit (progressziómentes túlélés: 1,9 vs. 3,8 hónap, HR: 1,5, 95\% CI: 1,0-2,2; $\mathrm{p}=0$ 0,03; teljes túlélés: 7,9 vs. 24,6 hónap, HR: 4,4, 95\% CI: 2,6-7,7; p<0,01) [27]. Az eredmények alátámasztják, hogy az antibiotikumok által előidézett dysbiosis a bél mikrobiom-összetételének megváltoztatásán keresztül jelentősen befolyásolja az IEG-kezelés elleni rezisztenciát.

Később hasonló eredmények láttak napvilágot melanomával kapcsolatban is. Több, független betegcsoporton végzett vizsgálat esetében igazoltak összefüggést az IEG-terápiával kezelt betegek rövidebb progressziómentes és/vagy teljes túlélése, valamint az antibiotikumkezelés között [26-39] (2. táblázat). Ezekben a vizsgálatokban azonban az antibiotikumhasználat és az immunterápia között eltelt idő, az antibiotikumkezelés hossza, illetve a használt hatóanyag tekintetében még nem sikerült egyértelmú következtetéseket levonni. Összességében az látszik, hogy 3 hónappal az immunkezelés megkezdése elött alkalmazott antibiotikumkezelés kettő-négyszeresére növeli a terápia sikertelenségének kockázatát. Nem teljesen tisztázott azonban, hogy minden esetben káros-e az antibiotikumkezelés az immunterápia hatékonyságára nézve, vagy esetleg célzott antibiotikumkezeléssel az immunterápia-érzékenység szempontjából kedvező irányba is eltolható a mikrobiom-összetétel.

Vétizou és mtsai eredményei szerint a vankomicinkezelés a Gram-pozitív baktériumoknak, fóként a Clostridi ales rend tagjainak eliminálásával javíthatja az immunterápia (anti-CTLA4) hatékonyságát. Ennek oka feltételezhetően a Gram-negatív Bacteroidales rend tagjainak elszaporodása, melyek fokozzák az l-es típusú segítő T-sejtek $\left(\mathrm{T}_{\mathrm{H}} \mathrm{l}\right)$ által közvetített immunválaszt [18]. $\mathrm{Az}$ antibiotikumokon kívül vizsgálták egyéb, az immunterápia megkezdése előtt/alatt alkalmazott gyógyszerek hatását is. Egy 640, nem kissejtes tüdőrákos beteget tartalmazó tanulmányban vizsgálták a kortikoszteroidkezelés IEG-terápiára gyakorolt hatását. Kimutatták, hogy közvetlenül a terápia megkezdése előtt alkalmazott folyamatos, napi legalább 10 mg dózist meghaladó kortikoszteroidkezelés mind univariancia-, mind multivariancia-analízisben szignifikáns összefüggést mutatott a betegek rövidebb progressziómentes, illetve teljes túlélésével [40]. Protonpumpagátlók esetében is hasonló eredményekre jutottak melanomában szenvedő betegek vonatkozásában [4l].

A fent leírt kísérletek eredményei alapján úgy tûnik, hogy a széklet összetételének mesterséges - például transzplantáció útján történő - megváltoztatása javíthatja az egyes gyógyszeres kezelések hatékonyságát [21, 22]. Erre az elképzelésre alapozva felmerült az emberből emberbe történő széklettranszplantáció lehetősége. Jelenleg több, prospektív klinikai vizsgálatban kutatják (NCT03353402, NCT03341143), hogy IEG-terápiára érzékeny betegek székletének rezisztens betegekbe történő transzplantációjával megfordítható-e a rezisztencia [15].

\section{Mikrobiom a vizeletben}

A vizelet mikrobiom-egyensúlyának megbomlása számos urológiai elváltozásra befolyással lehet, mint például az incontinentia, cystitis, hiperaktív hólyag vagy húgyhólyagdaganat [42]. A prosztatarákhoz hasonlóan a húgyhólyag esetében is igazolták, hogy a gyulladásos folyamatok növelik a daganat kialakulásának kockázatát. Ezen folyamatok és szöveti károsodások növelik a reaktív oxigénformák (szuperoxid-anion-gyök, hidrogén-peroxid, nitrogén-monoxid) képződését, melyek előidézik a DNS törését, károsítják az RNS-t, a lipideket és a fehérjéket. Mindemellett a sejtek növekedését és a tumorok képződését is befolyásolják, leginkább a DNS-javító mechanizmusok gátlásán és az angiogenesis elősegítésén keresztül [43]. A baktériumok a proteázaktivitásukon keresztül képesek megbontani az extracelluláris mátrix szerkezetét, valamint a citokinek múködésében zavart okozva gyengítik a szervezet immunválaszát. A leggyakrabban előforduló baktériumtaxonok: Lactobacillus, Corynebacterium, Staphylococcus, Prevotella, Gardnerella, Streptococcus.

A nők és a férfiak vizeletének baktérium-összetételében is különbségek mutatkoznak; a Lactobacillus, a Prevotella és a Gardnerella a nóknél, míg a Corynebacterium a férfiaknál van jelen nagyobb arányban. A mikrobiom-összetétel azonban az életkor előrehaladtával is változik [15, 44, 45]. Egy, a közelmúltban publikált tanulmányban Pederzoli és mtsai leírták a női, illetve a férfi hólyagdaganatos betegek vizeletének mikrobiom-összetételében mutatkozó különbségeket. Míg a férfiak vizeletében az Opitutales rend tagjai, addig a nói betegek esetében a Klebsiella nemzetség tagjai voltak jelen nagyobb mennyiségben. Ez utóbbi nemzetséghez tartozó baktériumok által a hólyagban termelt genotoxikus anyagok (például colibactin) nagyban hozzájárulhatnak a tumorképződéshez. A kutatócsoport a vizeletmintákon kívül tumoros, illetve normálszövetmintákat is vizsgált, és meghatározta ezek mikrobiom-összetételét is. Mindkét nem esetében szignifikánsan magasabb számban voltak jelen a Burkholderia nemzetséghez tartozó baktériumok a tumoros szövetben a normálurotheliumhoz viszonyítva. Ezenkívül sikerült igazolni, hogy a vizeletben található mikrobiomot több mint $80 \%$-ban ugyanazok a baktériumcsaládok alkotják, melyek a szövetmintában is azonosíthatók voltak. Ezen eredmény fényében feltételezhetjük, hogy a vizeletben azonosított mikrobiom megfelelően tükrözheti az urothelium környezetében előforduló baktériumflórát [46].

A vizelet-mikrobiom és a hólyagdaganat közötti öszszefüggésre mutat rá Wu és mtsai (2018) kutatása, mely- 
ben egészséges és húgyhólyagdaganatban szenvedő férfiak vizeletének mikrobiom-összetételét vizsgálták. Eltérést az Acinetobacter és az Anaerococcus nemzetségben találtak, melyek nagyobb mennyiségben voltak jelen daganatos férfiak vizeletében. Ezen baktériumok jelenléte gyulladásos folyamatokat indukál az epithelialis sejtréteg betörésén és az extracelluláris mátrix átalakításán keresztül, melyek megkönnyítik a baktériumok invázióját. Eredményeik alapján nemcsak a daganatos betegek mikrobiom-összetétele különbözött az egészséges kontrollcsoportétól, de a különböző differenciáltságú és a daganatkiújulás szempontjából különböző rizikócsoportokba tartozó betegek között is találtak különbségeket, melyek alapján a magasabb fajgazdagság kedvező prognosztikus faktor lehet a daganat kiújulására és progressziójára nézve [42]. Ezzel szemben egy másik vizsgálatban nem találtak különbséget az egészséges és a hólyagdaganatos férfiak vizeletének baktérium-összetételében, habár a fajok száma ebben az esetben is jelentős különbségeket mutatott a két vizsgált csoport között. A daganatos személyeknél a következő nemzetségek baktériumai voltak jelen magasabb fajszámban: Fusobacterium, Actinobaculum, Facklamia, továbbá a Ruminococcaceae család növekedett jelenlétét is igazolták. Ezzel szemben a korban megegyező, egészséges férfiak vizeletében a Veillonella, Streptococcus, Corynebacterium nemzetségek voltak jelen megnövekedett mennyiségben [47].

A vizeletben megtalálható baktériumok direkt módon befolyásolhatják a BCG-terápia hatékonyságát, mely a magas kockázatú, nem izominvazív húgyhólyagrák recidívájának és progressziójának megelőzésére használt standard terápia. A kezelés során élő, legyengített Mycobacterium bovist juttatnak közvetlenül, instillatio útján a húgyhólyagba, amely gyulladást idéz elő. A gyulladás következtében kiváltott lokális immunválasz pedig hozzájárul a tumorsejtek elpusztításához, így csökkentve a nem izominvazív hólyagdaganatok kiújulásának kockázatát. Állatkísérletek során bizonyították, hogy a BCG a bakteriális sejtfalon keresztül kölcsönhatásba kerül az urotheliummal annak fibronektin komponensein keresztül, ez pedig fontos szereppel bír a terápiás hatás kifejlődése szempontjából, hiszen e nélkül a baktériumok egyszerüen kimosódnak a húgyhólyagból [48]. Ám nemcsak a BCG, hanem más, a húgyhólyagban esetlegesen jelen lévő baktériumok is kölcsönhatásba kerülhetnek az urotheliummal, ezáltal befolyásolva a BCG-baktériumok daganatsejtekhez kötődését és így a terápia hatékonyságát [15], így tehát a húgyhólyagban jelen lévő baktériumok összetétele a BCG-kezelés hatékonyságát is nagyban befolyásolhatja.

\section{Következtetés}

Napjainkban a széklet és a vizelet mikrobiom-összetételének elemzése egyre aktívabban képezi a kutatások tárgyát. Az elmúlt 5 évben többféle daganattal kapcsolatban is számos új és releváns információ látott napvilágot a baktériumközösségek összetételének lehetséges prognosztikai szerepéről. Ezenfelül meggyőző eredmények bizonyítják a székletmikrobiom és az egyes IEG-kezelések hatékonysága közötti szoros összefüggést. További kutatások pedig felvetették a prosztata- és húgyhólyagdaganatos betegek vizeletmikrobiom-összetételének prognosztikus értékét is. Összességében a jövőben a gastrointestinalis és a vizelet-mikrobiom összetételének az egyénre szabott terápiás döntéshozatalban is jelentősége lehet. Ennek fényében különös figyelem irányul azon gyógyszerek alkalmazására (antibiotikumok, szteroidok), melyekról ismert, hogy befolyásolják a mikrobiom-összetételt. A jelenleg folyamatban lévő prospektív, klinikai kutatások fogják megválaszolni azt a kérdést, hogy a mikrobiom mesterséges, célzott megváltoztatása milyen terápiás előnyöket jelenthet a különböző malignus betegségek gyógyításában.

Anyagi támogatás: A cikk az NKFIH (FK 12443), az NVKP (16-1-2016-004) és a Bolyai János Kutatási Ösztöndíj támogatásával készültt.

Szerzői munkamegosztás: O. Cs., V. M.: Irodalomkutatás, a kézirat megírása, összeállítása. Sz. T.: A téma felvetése, a kézirat megírása, a kézirat javítása. H. O., Ny. P.: A kézirat véleményezése. A közlemény végleges változatát valamennyi szerző elolvasta és jóváhagyta.

Érdekeltségek: A szerzőknek a jelen cikkel kapcsolatban nincsenek érdekeltségeik.

\section{Irodalom}

[1] Barna I, Nyúl D, Szentes T, et al. Review of the relation between gut microbiome, metabolic disease and hypertension. [A bélmikrobiom, a metabolikus betegségek és a hypertonia kapcsolatának irodalmi áttekintése.] Orv Hetil. 2018; 159: 346-351. [Hungarian]

[2] Fekete Sz, Szabó D, Tamás L, et al. The role of the microbiome in otorhinolaryngology. [A mikrobiom szerepe a fül-orrgégészetben.] Orv Hetil. 2019; 160: 1533-1541. [Hungarian]

[3] Bersanelli M, Santoni M, Ticinesi A, et al. The urinary microbiome and anticancer immunotherapy: the potentially hidden role of unculturable microbes. Target Oncol. 2019; 14: 247-252.

[4] Goodman B, Gardner H. The microbiome and cancer. J Pathol. 2018; 244: 667-676.

[5] Francescone R, Hou V, Grivennikov IS. Microbiome, inflammation and cancer. Cancer J. 2014; 20: 181-189.

[6] Chaudhary N, Sharma AK, Agarwal P, et al. 16S classifier: a tool for fast and accurate taxonomic classification of $16 \mathrm{~S}$ rRNA hypervariable regions in metagenomic datasets. PLoS ONE 2015; 10: e0116106.

[7] Dave M, Higgins PD, Middha S, et al. The human gut microbiome: current knowledge, challenges, and future directions. Transl Res. 2012; 160: 246-257.

[8] Moustafa A, Li W, Singh H, et al. Microbial metagenome of urinary tract infection. Sci Rep. 2018; 8: 4333.

[9] Siddiqui H, Nederbragt AJ, Lagesen K, et al. Assessing diversity of the female urine microbiota by high throughput sequencing of 16S rDNA amplicons. BMC Microbiol. 2011; 11: 244. 
[10] Wolfe AJ, Brubaker L. "Sterile urine" and the presence of bacteria. Eur Urol. 2015; 68: 173-174.

[11] Puhr M, De Marzo A, Isaacs W, et al. Inflammation, microbiota, and prostate cancer. Eur Urol Focus 2016; 2: 374-382.

[12] Gopalakrishnan V, Helmink BA, Spencer CN, et al. The influence of the gut microbiome on cancer, immunity, and cancer immunotherapy. Cancer Cell 2018; 33: 570-580.

[13] Picardo SL, Coburn B, Hansen AR. The microbiome and cancer for clinicians. Crit Rev Oncol Hematol. 2019; 141: 1-12.

[14] McQuade JL, Daniel CR, Helmink BA, et al. Modulating the microbiome to improve therapeutic response in cancer. Lancet Oncol. 2019; 20: e77-e91.

[15] Markowski MC, Boorjian SA, Burton JP, et al. The microbiome and genitourinary cancer: a collaborative review. Eur Urol. 2019; 75: 637-646.

[16] Alexander JL, Wilson ID, Teare J, et al. Gut microbiota modulation of chemotherapy efficacy and toxicity. Nat Rev Gastroenterol Hepatol. 2017; 14: 356-365.

[17] Xu X, Zhang X. Effects of cyclophosphamide on immune system and gut microbiota in mice. Microbiol Res. 2015; 171: 97-106.

[18] Vétizou M, Pitt JM, Daillère R, et al. Anticancer immunotherapy by CTLA- 4 blockade relies on the gut microbiota. Science 2015 ; 350: 1079-1084.

[19] Rosenberg JE, Hoffman-Censits J, Powles T, et al. Atezolizumab in patients with locally advanced and metastatic urothelial carci noma who have progressed following treatment with platinumbased chemotherapy: a single-arm, multicentre, phase 2 trial. Lancet 2016; 387: 1909-1920.

[20] Bellmunt J, Powles T, Vogelzang NJ. A review on the evolution of PD-1/PD-Ll immunotherapy for bladder cancer: the future is now. Cancer Treat Rev. 2017; 54: 58-67.

[21] Sivan A, Corrales L, Hubert N, et al. Commensal Bifidobacte rium promotes antitumor immunity and facilitates anti-PD-Ll efficacy. Science 2015; 350: 1084-1089.

[22] Matson V, Fessler J, Bao R, et al. The commensal microbiome is associated with anti-PD-1 efficacy in metastatic melanoma patients. Science 2018; 359: 104-108.

[23] Gopalakrishnan V, Spencer CN, Nezi L, et al. Gut microbiome modulates response to anti- PD-1 immunotherapy in melanoma patients. Science 2018; 359: 97-103.

[24] Frankel AE, Coughlin LA, Kim J, et al. Metagenomic shotgun sequencing and unbiased metabolomic profiling identify specific human gut microbiota and metabolites associated with immune checkpoint therapy efficacy in melanoma patients. Neoplasia 2017; 19: 848-855

[25] Chaput N, Lepage P, Coutzac C, et al. Baseline gut microbiota predicts clinical response and colitis in metastatic melanoma patients treated with ipilimumab. Ann Oncol. 2017; 28: 13681379.

[26] Routy B, Le Chatelier E, Derosa L, et al. Gut microbiome influences efficacy of PD-1-based immunotherapy against epithelial tumors. Science 2018; 359: 91-97.

[27] Derosa L, Hellmann MD, Spaziano M, et al. Negative association of antibiotics on clinical activity of immune checkpoint inhibitors in patients with advanced renal cell and non-small-cell lung cancer. Ann Oncol. 2018; 29: 1437-1444.

[28] Kaderbhai C, Richard C, Fumet JD, et al. Antibiotic use does not appear to influence response to nivolumab. Anticancer Res. 2017; 37: 3195-3200.

[29] Huemer F, Rinnerthaler G, Westphal T, et al. Impact of antibiotic treatment on immune-checkpoint blockade efficacy in advanced non-squamous non-small cell lung cancer. Oncotarget 2018; 9: 16512-16520.

[30] Ahmed J, Kumar A, Parikh K, et al. Use of broad-spectrum antibiotics impacts outcome in patients treated with immune checkpoint inhibitors. Oncoimmunology 2018; 7: el507670.
[31] Mielgo-Rubio X, Chara L, Sotelo-Lezama M, et al. MA10. 01 Antibiotic use and PD-1 inhibitors: shorter survival in lung cancer, especially when given intravenously. Type of infection also matters. J Thorac Oncol. 2018; 13: S389.

[32] Do TP, Hegde AM, Cherry CR, et al. Antibiotic use and overall survival in lung cancer patients receiving nivolumab. J Clin Oncol. 2018; 36(15 Suppl): el5109.

[33] Lalani A-KA, Xie W, Lin X, et al. Antibiotic use and outcomes with systemic therapy in metastatic renal cell carcinoma (mRCC). J Clin Oncol. 2018; 36(6 Suppl): 607.

[34] Galli G, Triulzi T, Proto C, et al. Association between antibioticimmunotherapy exposure ratio and outcome in metastatic non small cell lung cancer. Lung Cancer 2019; 132: 72-78.

[35] Elkrief A, El Raichani L, Richard C, et al. Antibiotics are associated with decreased progression-free survival of advanced melanoma patients treated with immune checkpoint inhibitors. Oncoimmunology 2019; 8: el568812.

[36] Ouaknine Krief J, Helly de Tauriers P, Dumenil C, et al. Role of antibiotic use, plasma citrulline and blood microbiome in advanced non-small cell lung cancer patients treated with nivolumab. J Immunother Cancer 2019; 7: 176.

[37] Tinsley N, Zhou C, Tan G, et al. Cumulative antibiotic use significantly decreases efficacy of checkpoint inhibitors in patients with advanced cancer. Oncologist 2020; 25: 55-63.

[38] Pinato DJ, Howlett S, Ottaviani D, et al. Antibiotic treatment prior to immune checkpoint inhibitor therapy as a tumor-agnostic predictive correlate of response in routine clinical practice. J Clin Oncol. 2019; 37(Suppl 8); abstr 147.

[39] Hakozaki T, Okuma Y, Omori M, et al. Impact of prior antibiotic use on the efficacy of nivolumab for non-small cell lung cancer. Oncol Lett. 2019; 17: 2946-2952.

[40] Arbour KC, Mezquita L, Long N, et al. Impact of baseline steroids on efficacy of programmed cell death-1 and programmed death-ligand 1 blockade in patients with non-small-cell lung cancer. J Clin Oncol. 2018; 36: 2872-2878.

[41] Homicsko K, Richtig G, Tuchmann F, et al. Proton pump inhibitors negatively impact survival of PD-1 inhibitor based therapies in metastatic melanoma patients. Ann Oncol. 2018; 29(Suppl 10): x39-x43.

[42] Wu P, Zhang G, Zhao J, et al. Profiling the urinary microbiota in male patients with bladder cancer in China. Front Cell Infect Microbiol. 2018; 8: 167.

[43] Michaud DS. Chronic inflammation and bladder cancer. Urol Oncol. 2007; 25: 260-268.

[44] Xu W, Yang L, Lee P, et al. Mini-review: Perspective of the microbiome in the pathogenesis of urothelial carcinoma. Am J Clin Exp Urol. 2014; 2: 57-61.

[45] Alfano M, Canducci F, Nebuloni M, et al. The interplay of extracellular matrix and microbiome in urothelial bladder cancer. Nat Rev Urol. 2016; 13: 77-90.

[46] Pederzoli F, Ferrarese R, Amato V, et al. Sex-specific alterations in the urinary and tissue microbiome in therapy-naive urothelial bladder cancer patients. Eur Urol Oncol. 2020; 3: 784-788.

[47] Bučević Popović V, Šitum M, Chow CET, et al. The urinary microbiome associated with bladder cancer. Sci Rep. 2018; 8: 12157.

[48] Pettenati C, Ingersoll MA. Mechanisms of BCG immunotherapy and its outlook for bladder cancer. Nat Rev Urol. 2018; 15: 615-625.

A cikk a Creative Commons Attribution 4.0 International License (https://creativecommons.org/licenses/by/4.0/) feltételei szerint publikált Open Access közlemény. (SID_1) 